\title{
The Independence of the
}

Lysolecithinase Activity of Extracts of Clostridium sordellii from Their Lethal, Oedema-producing and Haemorrhagic Actions

\author{
By JANE MELLANBY AND AILSA B. WHITE \\ Sir William Dunn School of Pathology \\ University of Oxford
}

(Accepted for publication 23 February i968)

SUMMARY

\begin{abstract}
Extracts (ultrasonic treatment) of Clostridium sordellii contained a lysolecithinase, which was activated by ether, calcium ions and ammonium sulphate and inhibited by EDTA, magnesium and manganese. The enzyme was not responsible for the lethality, oedema-producing or haemorrhagic actions of extracts of the organism.
\end{abstract}

\section{INTRODUCTION}

Extracts of Clostridium sordellii are lethal and dermonecrotic (see for example Brooks \& Epps, 1959), and intradermal injection produces lesions involving haemorrhagic areas of skin with underlying gelatinous oedema. It is not known to what enzymic action the pathological effects may be ascribed. Lewis \& Macfarlane (I953) confirmed the observation of Miles \& Miles (1947) that a phospholipase C can be produced by $C$. sordellii (bifermentans). Although this enzyme is toxic, it is much less toxic per unit of phospholipase activity than the antigenically similar phospholipase $\mathrm{C}$ produced by $C$. welchii. Moreover, in the present work a strain of $C$. sordellii was used which does not produce a phospholipase $\mathrm{C}$ and yet culture filtrates and extracts of the organism are nevertheless lethal and dermonecrotic.

During a search for other lipolytic enzymes which might be responsible for the pathological action of Clostridium sordellii, it was found that the organism consistently produced a lysolecithinase. Arseculeratne (I965) had produced preliminary evidence, in this laboratory, that such an enzyme might be produced. Since lysolecithin is a more toxic substance than glycerylphosphorylcholine, the product of lysolecithinase activity, one might perhaps not expect a lysolecithinase to have any pathological activity. On the other hand, lysolecithin is probably a component of natural membranes and therefore its breakdown might result in pathological effects. To investigate whether there was any correlation between lysolecithinase activity and the pathological action of $C$. sordellii two approaches were used. Firstly, the organism was grown for 4,8 and $\mathrm{I} 2 \mathrm{hr}$ and the various activities measured in culture supernatant fluids, in extracts made by ultrasonic treatment and in saline extracts of the bacteria at these three times. It was hoped to see whether there was any correlation, in time of production or extractability, between the activities. Secondly, the enzyme was put through a 6-fold purification step and the pathological activities of the fractions with low and high lysolecithinase specific activities compared. 


\section{METHODS}

Lysolecithin and lysophosphatidylethanolamine (prepared from lecithin and phosphatidylethanolamine, respectively, by the action of snake venom phospholipase A) and Ancistrodon piscivorus venom were obtained from Koch-Light Laboratories Ltd (Colnbrook, Buckinghamshire, England).

The strain of Clostridium sordellii used was kindly provided by the Wellcome Research Laboratories. The organism was grown for $4 \mathrm{hr}$ at $37^{\circ}$, in I l. flasks or Io 1 . bottles, in a medium containing: $30 \mathrm{~g}$. Oxoid Bacteriological Peptone, $7.5 \mathrm{~g}$. Na- $\beta$-glycerophosphate and $0 . \mathrm{I} \mathrm{ml}$. of neutralized thiolacetic acid (approximately 0.3 mmoles), in $\mathrm{I} 1$. water. This medium was inoculated with an inoculum ( $2 \mathrm{ml}$.) of a culture grown overnight in cooked meat medium, which had itself been inoculated per Io $\mathrm{ml}$. with I drop of a spore suspension (containing equiv. IOO $\mathrm{mg}$. dry wt $/ \mathrm{ml}$.) which had been stored in $50 \%(\mathrm{v} / \mathrm{v})$ glycerol in water at $-40^{\circ}$. The bacteria were collected by centrifugation and washed once in $1 / 5$ of the original volume of $0.9 \%$ sodium chloride. The equiv. dry weight of organisms in the culture was estimated by measuring the extinction at $600 \mathrm{~m} \mu$ of a suitably diluted sample. There was a linear relation between equiv. dry weight and $E_{600}$ over a range of readings up to 0.60 . A reading of 0.300 on the spectrophotometer corresponded to $0.7 \mathrm{mg}$. dry wt organism/ $\mathrm{ml}$.

The bacteria were centrifuged down (at $10,000 \mathrm{~g}$ for $10 \mathrm{~min}$.), resuspended in water and given ultrasonic treatment for Io min. in an MSE sonicator (using a power of I00 W). The broken suspension was then centrifuged at $17,000 \mathrm{~g}$ for $10 \mathrm{~min}$; the supernatant fluid constituted the sonic extract. This was passed through a Seitz bacteriological filter and the protein in the extract precipitated by adding solid ammonium sulphate $\left(707 \mathrm{~g} . / 1\right.$.), keeping the mixture at $2^{\circ}$ and $\mathrm{pH} 7 \cdot 5$. This ammonium sulphate precipitate contained large amounts of material with an absorption at $260 \mathrm{~m} \mu$, which was not separated from the lysolecithinase activity by pretreatment with protamine sulphate and nucleases, precipitation with acid or passing the preparation through G 75 Sephadex.

The purification step adopted gave a 6-fold increase in specific activity. The procedure involved adsorbing the enzyme from a solution (in water) of the ammonium sulphate precipitate of the sonic extract, on to calcium phosphate, by adding (at $4^{\circ}$ ) $0 . \mathrm{I}$ volume of $0.2 \mathrm{M}-\mathrm{Na}_{2} \mathrm{HPO}_{4}$ followed by 0.05 volume of $\mathrm{M}-\mathrm{CaCl}_{2}$; the mixture was adjusted to $\mathrm{pH} 7.5$ and allowed to stand at $4^{\circ}$ for $30 \mathrm{~min}$. The suspension was then centrifuged in the cold at $12,000 \mathrm{~g}$ for $10 \mathrm{~min}$. The precipitate was stirred gently at $2^{\circ}$ for 30 min. with ammonium sulphate solution (containing $177 \mathrm{~g} . / 1 .=0.25$ saturated) at $\mathrm{pH} 7 \cdot 5$. The suspension was then recentrifuged; the supernatant fluid contained the 6-fold purified enzyme.

Protein was estimated by the technique of Lowry, Rosebrough, Farr \& Randall (I95I) on samples which had been dialysed for at least $6 \mathrm{hr}$ against running cold water.

Lethality of preparations was investigated by injecting pairs of Swiss albino mice intramuscularly with 2-fold serial dilutions prepared in gelatin buffer ( $0 \cdot$ I M-phosphate buffer $(\mathrm{pH} 7 \cdot 0$ ) containing $0.2 \%$ gelatin). One LD 50 dose was defined as the dose which killed within $72 \mathrm{hr}$ half the mice injected.

A rough assay system was worked out for oedema-producing and haemorrhagic 
effects. Comparisons of the activity of different preparations were made by injecting equal amounts of protein, dissolved in $0.1 \mathrm{ml}$. gelatin buffer (see above), into the shaved flank skin of albino guinea pigs. The skins were examined $4 \mathrm{hr}$ after injection and the degrees of oedema and haemorrhage assessed on an arbitrary relative scale, $([ \pm],+,++,+++)$ from the external and internal post-mortem appearances. The lesions usually appeared as dark-red round haemorrhagic patches up to $10-15 \mathrm{~mm}$. diam., sometimes with a paler area of necrosis in the middle. Where there was much oedema factor, the oedema spread all round the injected side of the animal as a thick gelatinous layer and the skin adhered tightly to the underlying fascia. However. where there was little oedema factor, the oedema remained as a bleb around the site of injection.

Thin-layer chromatography was done on Kieselgel-G (nach Stahl; Shandon). Incubation mixtures of phospholipid and enzyme were extracted with chloroform + methanol $(2+\mathrm{I}, \mathrm{v} / \mathrm{v})$, the lower chloroform layers were evaporated to dryness and the residue was taken up in $I / 5$ volume or less of chloroform + methanol $(2+I, v / v)$. The solutions were loaded on to the plate in streaks $(\mathrm{I} \mathrm{cm}$.) and the plate developed by ascending chromatography in chloroform + methanol + water $(60+30+5$, by vol.). The spots were located by spraying the dried plates lightly with sulphuric acid + water $(\mathrm{I}+\mathrm{I}, \mathrm{v} / \mathrm{v})$ and heating at $160^{\circ}$ for about $30 \mathrm{~min}$.

The action of a sonic extract of Clostridium sordellii on purified lysolecithin was demonstrated by comparing the thin-layer chromatograms of $(a)$ lysolecithin alone, (b) lecithin alone, $(c)$ an extract from an incubation mixture of lecithin and the phospholipase A of the venom of Ancistrodon piscivorus, and $(d)$ an extract from an incubation mixture of lysolecithin and a sonic extract of $C$. sordellii. The chromatogram from $(c)$ showed the lecithin spot replaced by a lysolecithin spot and a fast-moving spot corresponding to the free fatty acid liberated by the phospholipase $\mathrm{A}$; in the chromatogram from $(d)$ the lysolecithin spot was absent, but a free fatty-acid spot similar to that in $(c)$ was present. This showed that the sonic extract of $C$. sordellii contained a lysolecithinase liberating free fatty acid from lysolecithin.

\section{Assay of lysolecithinase activity}

The preparations from Clostridium sordellii were incubated with lysolecithin $(0.25 \mathrm{mg} . / \mathrm{ml}$.) in phosphate buffer $(0.004 \mathrm{M} ; \mathrm{pH} 7.5)$ in a final volume of $1 \mathrm{ml}$. +initially $\mathrm{I} \mathrm{ml}$. ether, at $30^{\circ}$ for $30 \mathrm{~min}$. The reaction was started by adding the enzyme and stopped by placing the mixture in ice and adding $5 \mathrm{ml}$. of extraction mixture (iso-propylalcohol $+n$-heptane $+2 \mathrm{~N}_{-} \mathrm{H}_{2} \mathrm{SO}_{4} ; 80+20+\mathrm{I}$, by vol.). The free fatty acids extracted were then titrated after the method described by Kelley (1965) with $\mathrm{N} / 200$ tetra- $n$-butyl ammonium hydroxide in methanol, by using an automatic titrator (Radiometer, Copenhagen; type ABU I b; supplied by V. A. Howe, London).

\section{RESULTS}

\section{Some properties of the lysolecithinase}

When ether was added to the incubation mixture it was found that a constant rate of reaction for at least $30 \mathrm{~min}$. was obtained. In the absence of ether the rate decreased after the first $5 \mathrm{~min}$. There was an optimal value around $\mathrm{pH} 7 \cdot 5$; for a $15 \mathrm{~min}$. incubation period (in the absence of ether) the optimal temperature was around $30^{\circ}$; 
in the presence of ether the activity of the enzyme was decreased by EDTA and magnesium and manganese salts (O.OI $\mathrm{M}$ final concentration); and it was completely inhibited (in the absence of ether) by deoxycholate (0.01 $2 \mathrm{M})$; it was activated by calcium chloride (0.01 M) and by ammonium sulphate $(3.5 \mathrm{M})$. With lysophosphatidylethanolamine as substrate for the enzyme (in the presence of ether) the reaction proceeded at about half the rate of that with lysolecithin.

\section{Effect of time of incubation of Clostridium sordellii on the production of lysolecithinase and other active substances}

A comparison was made of the lysolecithinase activity, the lethality (in mice), haemorrhage-producing and oedema-producing actions (in guinea-pig skin), haemolytic activity, and proteolytic activity of supernatant fluids and extracts from the C. sordellii incubated and harvested at 4,8 or $\mathrm{I} 2 \mathrm{hr}$. Table I shows that the lyso-

\section{Table I. Production of various biological activities by a culture of Clostridium sordellii}

Samples of the culture were taken after incubation for 4, 8 and $12 \mathrm{hr}$. Activities were measured in the culture supernatant fluid and in sonic extracts of the organisms. The results from two similar experiments are given. The activities are given per ml. of original culture.

\begin{tabular}{|c|c|c|c|c|c|c|}
\hline & \multicolumn{6}{|c|}{ Time of incubation } \\
\hline & \multicolumn{2}{|c|}{$4 \mathrm{hr}$} & \multicolumn{2}{|c|}{$8 \mathrm{hr}$} & \multicolumn{2}{|c|}{$12 \mathrm{hr}$} \\
\hline & $\begin{array}{l}\text { Supernatant } \\
\text { fluid }\end{array}$ & $\begin{array}{l}\text { Sonic } \\
\text { extract }\end{array}$ & $\begin{array}{l}\text { Supernatant } \\
\text { fluid }\end{array}$ & $\begin{array}{l}\text { Sonic } \\
\text { extract }\end{array}$ & $\begin{array}{l}\text { Supernatant } \\
\text { fluid }\end{array}$ & $\begin{array}{l}\text { Sonic } \\
\text { extract }\end{array}$ \\
\hline $\mathrm{LD}_{50}$ & $\begin{array}{r}80 \\
8\end{array}$ & $\begin{array}{r}<10,000 \\
3,840\end{array}$ & $\begin{array}{l}1,600 \\
1,920\end{array}$ & $\begin{array}{r}4,800 \\
960\end{array}$ & $\begin{array}{l}1,600 \\
2,560\end{array}$ & $\begin{array}{l}9,600 \\
1,920\end{array}$ \\
\hline Lysolecithinase & $\begin{array}{l}>0.1 \\
>0.1\end{array}$ & $\begin{array}{l}0.45 \\
2 \cdot 8\end{array}$ & $\begin{array}{l}>0.1 \\
>0.1\end{array}$ & $\begin{array}{l}0 \cdot 43 \\
\mathrm{I} \cdot 4\end{array}$ & $\begin{array}{r}0.3 \\
>0.1\end{array}$ & $\begin{array}{l}0 \cdot 40 \\
2 \cdot 2\end{array}$ \\
\hline $\begin{array}{l}\text { Haemorrhagic } \\
\text { activity }\end{array}$ & $\begin{array}{l}0 \\
0\end{array}$ & $\begin{array}{l}+++ \\
+++\end{array}$ & $\begin{array}{l}++ \\
++\end{array}$ & $\begin{array}{l}++ \\
++\end{array}$ & $\begin{array}{l}++ \\
++\end{array}$ & $\begin{array}{l}+t \\
+t\end{array}$ \\
\hline Oedema activity & $\begin{array}{l}0 \\
0\end{array}$ & $\begin{array}{c}++ \\
0\end{array}$ & $\begin{array}{l} \pm \\
0\end{array}$ & $\begin{array}{l}+ \\
++\end{array}$ & $\begin{array}{l}t \\
t\end{array}$ & $\begin{array}{l} \pm \\
+\end{array}$ \\
\hline $\begin{array}{l}\text { Haemolysis } \\
\text { units }\end{array}$ & $\begin{array}{l}7 \cdot 2 \\
10\end{array}$ & $\begin{array}{l}0.02 \\
0.08\end{array}$ & $\begin{array}{l}4 \cdot 1 \\
6 \cdot 5\end{array}$ & $\begin{array}{l}0.02 \\
0.08\end{array}$ & $\begin{array}{l}2 \cdot 8 \\
5 \cdot 8\end{array}$ & $\begin{array}{l}0.02 \\
0.10\end{array}$ \\
\hline Protease & $\begin{array}{l}0.61 \\
0.72\end{array}$ & $\begin{array}{l}0.03 \\
0.045\end{array}$ & $\begin{array}{l}0.8 I \\
0.96\end{array}$ & $\begin{array}{l}0.03 \\
0.045\end{array}$ & $\begin{array}{l}0.65 \\
I .02\end{array}$ & $\begin{array}{l}0.03 \\
0.04\end{array}$ \\
\hline
\end{tabular}

lecithinase activity remained within the organisms for at least $8 \mathrm{hr}$ and was still mainly intracellular after $\mathrm{I} 2 \mathrm{hr}$. On the other hand, very weak proteolytic and haemolytic activities, almost paralleling each other, were found almost exclusively in the culture supernatant fluid. Oedema-producing activity was also unrelated to lysolecithinase activity, since it was decreasing between 4 and I $2 \mathrm{hr}$ while the lysolecithinase remained approximately constant over this period. From this kind of experiment it was not possible to say whether or not there was any relation between lysolecithinase activity and the haemorrhagic (guinea-pig skin) activity.

\section{Pathological activities of preparations differing in their lysolecithinase content}

In Table 2 the pathological activities of two preparations whose lysolecithinase activity differed about 7 -fold are compared. The two preparations were the super- 
natant fluid (CaSF) after most of the lysolecithinase activity of a sonic extract of Clostridium sordellii had been adsorbed on calcium phosphate, and the material, enriched in lysolecithinase activity, eluted from the calcium phosphate with 0.25 saturated ammonium sulphate $(0.25 \mathrm{SF})$. It can be seen that the haemorrhagic

Table 2. Pathological activities of preparations from Clostridium sordellii differing in their lysolecithinase content

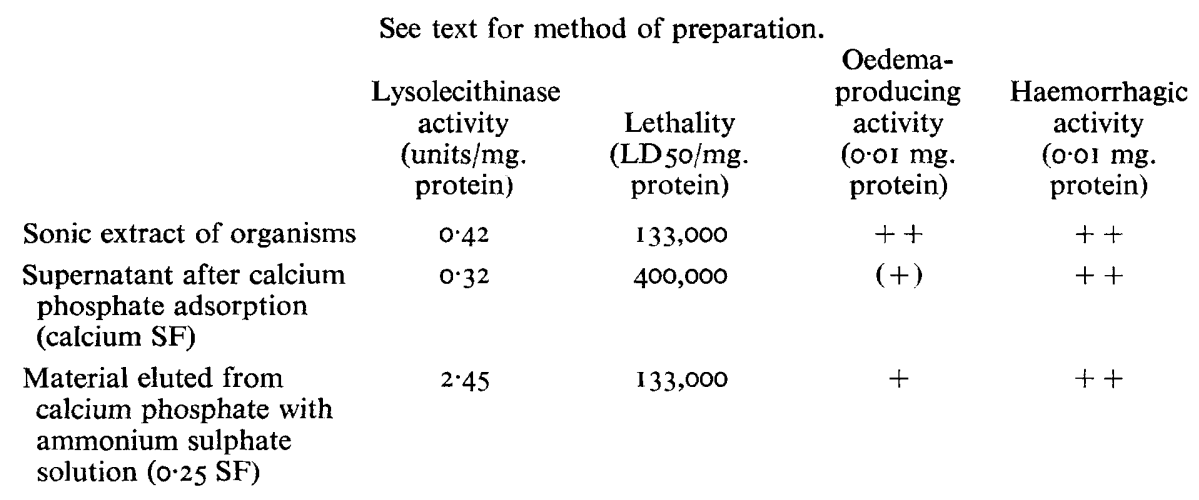

activity of the two preparations was the same; hence the lysolecithinase was independent of the haemorrhagic activity. It was confirmed that lysolecithinase was independent of the lethality. Table 2 also further illustrates (as can be seen in Table I) that the oedema factor was not chiefly responsible for the lethal action of preparations from $C$. sordellii, and that the oedema and haemorrhagic factors could be independent. It can be concluded that the lysolecithinase of $C$. sordellii is not responsible for the lethal, oedema-producing or haemorrhagic activity of extracts of this organism.

We thank Dr D.S. Robinson of the Department of Biochemistry, Oxford, for his help, particularly with the estimation of free fatty acids; and Mr P. A. Thompson for skilled technical assistance. This work was done under contract (Project no. I03474) between the Office of Naval Research of the United States Department of the Navy and Dr W. E. van Heyningen, to whom we are grateful for advice and encouragement.

\section{REFERENCES}

Arseculeratne, S. N. (1965). The toxins of Clostridium sordellii. D.Phil. thesis, University of Oxford.

Brooks, M. E. \& EPPS, H. B. G. (1959). Taxonomic Studies of the genus Clostridium: Clostridium bifermentans and C. sordellii. J. gen. Microbiol. 21, I44.

KElley, T. F. (1965). Improved method for microtitration of fatty acids. Analyt. Chem. 37, 1078.

Lewis, G. M. \& Macfarlane, M. G. (1953). The lecithinase of Clostridium bifermentans toxin. Biochem. J. 54, 138.

Lowry, O. H., Rosebrough, N. J., Farr, A. L. \& Randall, R. J. (I95I). Protein measurement with the Folin phenol reagent. J. biol. Chem. 193, 265.

Miles, E. M. \& Miles, A. A. (I947). The lecithinase of Clostridium bifermentans and its relation to $\alpha$-toxin of Clostridium welchii. J. gen. Microbiol. $\mathbf{1}, 385$. 